Marshall University

Marshall Digital Scholar

Biological Sciences Faculty Research

Biological Sciences

$7-1-2010$

\title{
Spatial heterogeneity of soil nutrients and plant species in herb-dominated communities of contrasting land use
}

Frank S. Gilliam

Marshall University, gilliam@marshall.edu

David A. Dick

Follow this and additional works at: http://mds.marshall.edu/bio_sciences_faculty

Part of the Ecology and Evolutionary Biology Commons, and the Plant Sciences Commons

\section{Recommended Citation}

Gilliam FS and DA Dick. 2010. Spatial heterogeneity of soil nutrients and plant species in herb-dominated communities of contrasting land use. Plant Ecology 209:83-94.

This Article is brought to you for free and open access by the Biological Sciences at Marshall Digital Scholar. It has been accepted for inclusion in Biological Sciences Faculty Research by an authorized administrator of Marshall Digital Scholar. For more information, please contact 


\section{ISSN 1385-0237, Volume 209, Number 1}

\section{Plant Ecology}

VOLUME 209 NUMBER 1 JULY 2010 ISSN 1385-0237 AN INTERNATIONAL JOURNAL

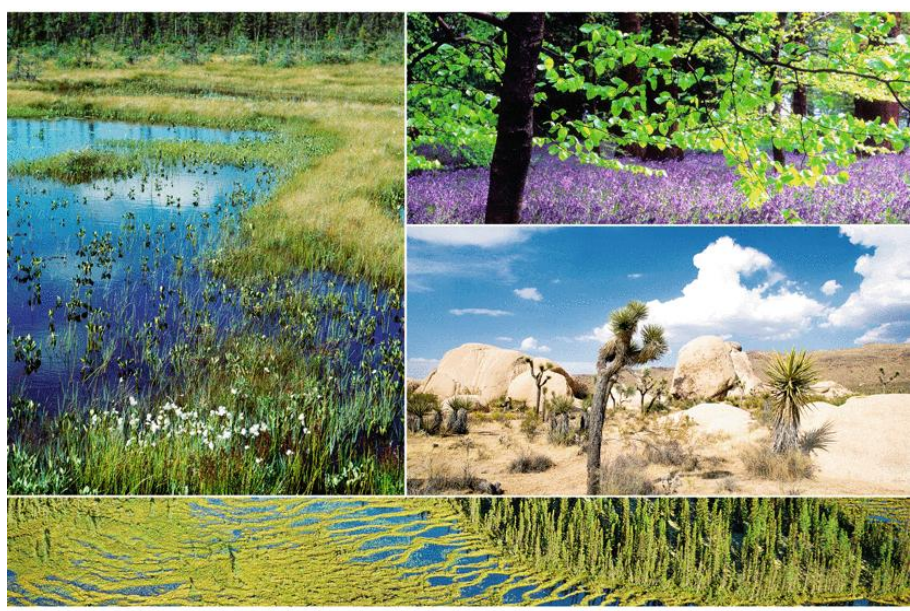

橧) Springer

This article was published in the above mentioned Springer issue.

The material, including all portions thereof, is protected by copyright; all rights are held exclusively by Springer Science + Business Media.

The material is for personal use only;

commercial use is not permitted.

Unauthorized reproduction, transfer and/or use

may be a violation of criminal as well as civil law. 


\title{
Spatial heterogeneity of soil nutrients and plant species in herb-dominated communities of contrasting land use
}

\author{
Frank S. Gilliam • David A. Dick
}

Received: 27 July 2009/Accepted: 15 January 2010/Published online: 29 January 2010

(C) Springer Science+Business Media B.V. 2010

\begin{abstract}
Recent interest in spatial pattern in terrestrial ecosystems has come from an awareness of the intimate relationship between spatial heterogeneity of soil resources and maintenance of plant species diversity. Soil and vegetation can vary spatially in response to several state factors of the system. In this study, we examined fine-scale spatial variability of soil nutrients and vascular plant species in contrasting herb-dominated communities (a pasture and an old field) to determine degree of spatial dependence among soil variables and plant community characteristics within these communities by sampling at $1-\mathrm{m}$ intervals. Each site was divided into $251-\mathrm{m}^{2}$ plots. Mineral soil was sampled $(2-\mathrm{cm}$ diameter, $5-\mathrm{cm}$ depth) from each of four $0.25-\mathrm{m}^{2}$ quarters and combined into a single composite sample per plot. Soil organic matter was measured as loss-on-ignition. Extractable $\mathrm{NH}_{4}$ and $\mathrm{NO}_{3}$ were determined before and after laboratory incubation (28 days at $27^{\circ} \mathrm{C}$ ) to determine potential net $\mathrm{N}$ mineralization and nitrification. Cations were analyzed using inductively coupled plasma emission spectrometry. Vegetation was assessed using estimated percent cover. Most soil
\end{abstract}

F. S. Gilliam $(\bowtie)$

Department of Biological Sciences, Marshall University, Huntington, WV 25755-2510, USA

e-mail: gilliam@marshall.edu

D. A. Dick

West Virginia Department of Agriculture, Plant Industries Division, Charleston, WV 25305-0191, USA and plant variables exhibited sharp contrasts between pasture and old-field sites, with the old field having significantly higher net $\mathrm{N}$ mineralization/nitrification, $\mathrm{pH}, \mathrm{Ca}, \mathrm{Mg}, \mathrm{Al}$, plant cover, and species diversity, richness, and evenness. Multiple regressions revealed that all plant variables (species diversity, richness, evenness, and cover) were significantly related to soil characteristics (available nitrogen, organic matter, moisture, $\mathrm{pH}, \mathrm{Ca}$, and $\mathrm{Mg}$ ) in the pasture; in the old field only cover was significantly related to soil characteristics (organic matter and moisture). Both sites contrasted sharply with respect to spatial pattern of soil variables, with the old field exhibiting a higher degree of spatial dependence. These results demonstrate that land-use practices can exert profound influence on spatial heterogeneity of both soil properties and vegetation in herb-dominated communities.

Keywords Herbaceous communities ·

Soil nutrients - Land-use history · Spatial pattern · Geostatistics

\section{Introduction}

Although temporal patterns of ecosystem processes, such as ecological succession and response to disturbance, have long served as a cornerstone of ecological research, there is considerable current interest in characterizing spatial heterogeneity in 
terrestrial ecosystems (Lovett et al. 2005). Much of this has arisen from an awareness of the intimate relationship between spatial heterogeneity of soil resources and maintenance of plant species diversity (Ricklefs 1977; Beatty 2003). Working with 144 $0.18 \mathrm{~m}^{2}$ plots on limestone pavements of southern Ontario, Canada, Lundholm and Larson (2003) found that peaks in species richness correlated most closely with maximum soil heterogeneity. Hutchings et al. (2003) suggested that the mechanism for such relationships arises from the alteration of interspecific competition brought about by spatial heterogeneity in soil resources. Significant responses of plant diversity to soil resource heterogeneity have been observed in studies that span virtually all spatial scales, from the plot (e.g., 1-m²) (Palmer 1990; Dick and Gilliam 2007), to the landscape (Dufour et al. 2006), and even on a global scale (Kreft and Jetz 2007). Loss of plant biodiversity in some terrestrial ecosystems has been linked to decreases in spatial heterogeneity of soil nutrients, such as nitrogen (N) (Gilliam 2006).

Indeed, although it has long been the bane of designs for field experiments (Dutilleul 1993), spatial heterogeneity is increasingly being considered an important, integral facet of terrestrial ecosystems (McClain et al. 2003; Lovett et al. 2005). The cycling of nutrients, particularly $\mathrm{N}$, in soils of terrestrial ecosystems is controlled by processes, such as microbial activity and vegetation dynamics, which often are quite spatially heterogeneous (Robertson et al. 1988; Parkin 1993; Schlesinger et al. 1996; Thompson et al. 2006; Housman et al. 2007). Relatively undisturbed terrestrial ecosystems typically display a high degree of spatial heterogeneity, with spatially discrete areas of high $\mathrm{N}$ mineralization rates in soils.

Spatial variability can be altered by a variety of disturbances (Fraterrigo and Rusak 2008; Xi et al. 2008). In particular, land-use practices can directly alter spatial heterogeneity of both soil resources and plant species of herb-dominated plant communities. For example, activities such as plowing and fertilizer application can influence the spatial pattern of soil organic matter and nutrients, especially N. Furthermore, harvesting and herbicide use can affect plant species composition, and grazing can simultaneously alter spatial heterogeneity of both soil resources and vegetation. Thus, variation in land use can exert a profound impact on soil-plant interactions, and do so in a way that can influence plant community composition (Eskelinen et al. 2009).

The purpose of this study was to examine finescale spatial variability of soil nutrients and vascular plant species in herb-dominated communities that vary in land-use: a pasture and an old field. More specifically, we wanted to determine the degree of spatial dependence of soil variables ( $\mathrm{N}$ dynamics, $\mathrm{pH}$, organic matter, and extractable soil nutrients) and plant community characteristics (cover, species richness, evenness, and diversity) within these communities by sampling at 1-m intervals.

\section{Methods}

Site description

This study was done at the Mill Creek mitigation area, a site that will become a constructed wetland to offset wetland losses incurred during road construction. It is located in a 3rd-order stream floodplain in Wayne County, West Virginia $\left(38^{\circ} 31^{\prime} \mathrm{N}, 82^{\circ} 42^{\prime} \mathrm{W}\right)$. Both pasture and old field comprise an approximately 1-ha area surrounded by uplands dominated by mixed deciduous forest. Long-term (30-year) mean precipitation is $107 \mathrm{~cm} \mathrm{year}^{-1}$; for the two years of study, precipitation was 93.1 and $117.1 \mathrm{~cm}$ in 2001 and 2002, respectively. Elevation within the floodplain is 195-200 m.

The study site was dominated by soils of the Kanawha series: fine-loamy, mixed, active, mesic Typic Hapludalfs, and very deep (100-180 cm). They are well-drained, moderately permeable, and formed in alluvium derived from interbedded shale, siltstone, and sandstone. Kanawha soils are found on high bottoms and low stream terraces with slope ranges from 0 to $15 \%$, typical of slopes of our study.

Evans et al. (2004) recognized these site types as two of nine cover types in the general Mill Creek area. The pasture site experiences regular grazing by domestic cattle, but does not undergo haying. The old-field site, abandoned at least 20 year prior to this study, exhibits few remaining characteristics of earlier agriculture (Evans et al. 2004), with grain crops commonly planted and harvested (Slagle et al. 2004). 
Field sampling

One 5-m $\times 5-\mathrm{m}$ sample site was established in each of two community types-an old field and a pasture-approximately $50 \mathrm{~m}$ apart. Each site was divided into 25 contiguous $1-\mathrm{m}^{2}$ plots, with each plot being quartered with a $1-\mathrm{m}^{2}$ PVC frame with center cross. One sample of mineral soil was taken from the center of each $0.25-\mathrm{m}^{2}$ quarter of each $1-\mathrm{m}^{2}$ plot to a depth of $5 \mathrm{~cm}$ with a $2-\mathrm{cm}$ diameter soil corer. This depth was chosen to represent maximum root distribution for this vegetation type (Schenk and Jackson 2002).

The four soil samples (one per quarter) were combined in a single sterile polyethylene Whirl-Pak ${ }^{\circledR}$ bag to create a composite sample for each $1-\mathrm{m}^{2}$ plot, a total of 25 mineral soil samples per site (Fig. 1). Samples were kept as intact cores in bags and placed

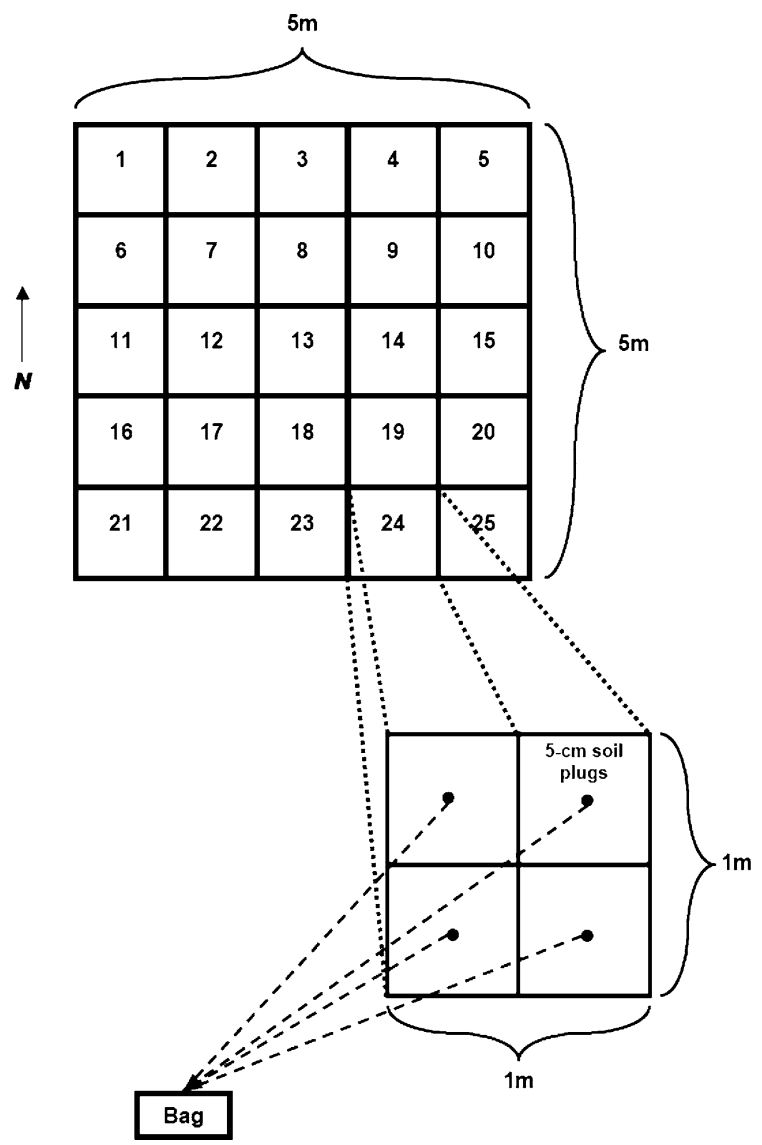

Fig. 1 Schematic diagram of sampling design within each of two sites immediately on ice for transport to the laboratory. Soils were collected in August 2001.

Above-ground plant cover was estimated within each $1-\mathrm{m}^{2}$ plot at pasture and old-field sites using percent cover estimation in October 2002 (Gilliam and Turrill 1993). Botanical nomenclature follows Strasbaugh and Core (1977).

Laboratory analyses

Upon transport to the Marshall University Weeds and Dirt Laboratory, samples were manually homogenized in original collection bags prior to extraction and analysis. Organic matter was determined from oven-dried sub-samples of soil using a loss-onignition method (mass lost over $7 \mathrm{~h}$ at $500^{\circ} \mathrm{C}$ ). Soils were also sub-sampled for extraction and preincubation analysis of $\mathrm{KCl}$-extractable $\mathrm{NO}_{3}, \mathrm{NH}_{4}$, $\mathrm{Al}, \mathrm{Ca}, \mathrm{Mg}$, and $\mathrm{pH}$. Extraction was performed on moist soil using $1 \mathrm{~N} \mathrm{KCl}$ at an extract:soil ratio of 10:1 (v:w). Extracts were analyzed for $\mathrm{NH}_{4}$ and $\mathrm{NO}_{3}$ colorimetrically with a Bran + Luebbe TrAAcs 2000 automatic analysis system. Extractable $\mathrm{Al}, \mathrm{Ca}$, and $\mathrm{Mg}$ were analyzed using inductively coupled plasma emission spectrometry (ICP) with a Varian Liberty 110 ICP Emission Spectrometer. Remaining soil samples were then incubated in their original polyethylene bags at $27^{\circ} \mathrm{C}$ for 28 days in a Fisher Scientific Low Temperature Incubator (Model 146E). Post-incubation extraction and analyses were conducted as above.

Extractable $\mathrm{N}$ pools were determined as the preincubation levels of $\mathrm{NH}_{4}$ and $\mathrm{NO}_{3}$. Net $\mathrm{N}$ mineralization was calculated as post-incubation $\mathrm{NH}_{4}$ plus $\mathrm{NO}_{3}$ minus pre-incubation $\mathrm{NH}_{4}$ plus $\mathrm{NO}_{3}$; net nitrification was calculated as post-incubation $\mathrm{NO}_{3}$ minus pre-incubation $\mathrm{NO}_{3}$. Because these are based on laboratory incubations, results reflect $\mathrm{N}$ mineralization and nitrification potentials, rather than field (i.e., in situ) rates.

Data analysis

Species diversity was calculated using the ShannonWiener Index $\left(\mathrm{H}^{\prime}\right)$, based on cover estimates and using $\ln$-transformed $p_{\mathrm{i}}$ values. The Pielou Index was used to determine species evenness $(J)$ (Barbour et al. 1999). Finally, species richness (i.e., species 
Table 1 List of all plant species encountered at Mill Creek study site, Wayne County, West Virginia

\begin{tabular}{|c|c|}
\hline Scientific name & Common name \\
\hline Acalypha rhomboidea Raf. & $\begin{array}{l}\text { Common three-seeded } \\
\text { mercury }\end{array}$ \\
\hline Ambrosia artemisiifolia $\mathrm{L}$. & Common ragweed \\
\hline Andropogon virginicus $\mathrm{L}$. & Broomsedge \\
\hline $\begin{array}{l}\text { Arthraxon hispidus (Thunb.) } \\
\text { Makino }\end{array}$ & Jointheaded arthraxon \\
\hline Aster pilosus Willd. & White heath aster \\
\hline Carex vulpinoidea Michx. & Foxtail sedge \\
\hline Cinna arundinacea $\mathrm{L}$. & Wood reed-grass \\
\hline Cirsium vulgare (Savi) Tenore & Common thistle \\
\hline Cyperus strigosus L. & Strawcolored Flatsedge \\
\hline Daucus carota $\mathrm{L}$. & Queen Anne's lace \\
\hline Digitaria sanguinalis (L.) Scop. & Crabgrass \\
\hline Elephantopus carolinianus Willd. & Elephant's-foot \\
\hline Erigeron canadensis $\mathrm{L}$. & Horseweed \\
\hline Eragrostis spectabilis (Pursh) Steud. & Purple lovegrass \\
\hline Eupatorium coelestinum L. & Mistflower \\
\hline Eupatorium serotinum Michx. & $\begin{array}{l}\text { Late-flowering } \\
\text { thoroughwort }\end{array}$ \\
\hline Festuca elatior L. & Meadow fescue \\
\hline Glechoma hederacea $\mathrm{L}$. & Ground-ivy \\
\hline Holcus lanatus L. & Velvet grass \\
\hline Juncus effusus L. & Common rush \\
\hline Juncus tenuis Willd. & Path rush, wiregrass \\
\hline $\begin{array}{l}\text { Lespedeza cuneata (Dumont) G. } \\
\text { Don }\end{array}$ & Sericea \\
\hline \multicolumn{2}{|l|}{ Lespedeza sp. } \\
\hline \multicolumn{2}{|l|}{ Medicago sp. } \\
\hline \multicolumn{2}{|l|}{ Muhlenbergia sp. } \\
\hline Oxalis stricta $\mathrm{L}$. & $\begin{array}{l}\text { Upright yellow wood } \\
\text { sorrel }\end{array}$ \\
\hline \multicolumn{2}{|l|}{ Panicum sp. } \\
\hline Panicum anceps Michx. & $\begin{array}{l}\text { Flat-stemmed panic } \\
\text { grass }\end{array}$ \\
\hline Panicum clandestinum $\mathrm{L}$. & Deertongue grass \\
\hline Paspalum laeve Michx. & $\begin{array}{l}\text { Smooth paspalum, } \\
\text { beadgrass }\end{array}$ \\
\hline Phaseolus polystachios (L.) BSP. & Wild kidney bean \\
\hline Plantago sp. & Plantain \\
\hline Potentilla simplex Michx. & Common cinqufoil \\
\hline Poa sp. & Bluegrass \\
\hline Ruellia caroliniensis (Walt.) Steud. & Wild-petunia \\
\hline Setaria glauca (L.) Beauv. & Yellow foxtail \\
\hline Setaria viridis (L.) Beauv. & Green foxtail \\
\hline Solanum carolinense $\mathrm{L}$. & Horse-nettle \\
\hline
\end{tabular}

Table 1 continued

\begin{tabular}{ll}
\hline Scientific name & Common name \\
\hline $\begin{array}{l}\text { Taraxacum officinale Weber. } \\
\text { Triodia flava } \text { (L.) Smyth }\end{array}$ & Common dandelion \\
$\begin{array}{l}\text { Trifolium pratense } \text { L. } \\
\text { Verbesina alternifolia } \text { (L.) Britton } \\
\text { ex Kearney }\end{array}$ & Purpletop \\
Vernonia altissima Nutt. & Tall ing-stem \\
\hline
\end{tabular}

density $-S$ ) was determined as number of species per $1-\mathrm{m}^{2}$ plot.

All response variables were tested for normality using Shapiro-Wilk test in Statistix 9.0 (Analytical Software 2008) prior to statistical analysis. Because all variables were normally distributed, they were used as untransformed data. Means were compared between pasture and old-field sites using $t$-tests (Zar 2009; Analytical Software 2008). Relationships among variables, sites, and vegetation were assessed with canonical correspondence analysis using CANOCO version 4.5.

Backward stepwise regression was used to identify soil factors as independent variables that more significantly correlate with plant variables-cover and species richness, evenness, and diversity. This technique sequentially eliminates variables from an original model with all soil variables until all the variables remaining in the model produce $F$ statistics significant at $P<0.05$ (Analytical Software 2008).

Degree of spatial dependence of soil and vegetation variables (as well as that of three individual species at each site) and its variation between sites was determined with geostatistics (Robertson 1987; Schlesinger et al. 1996; Iqbal et al. 2005). Using a spherical model, a semi-variogram was constructed for each variable with VESPER, version 1.62 (Minasny et al. 2005). Three possible patterns can arise from these analyses: spatial dependence, randomness, and linearity. Spatial dependence comprises four values relevant to spatial pattern: (1) nugget, which is microvariability (i.e., variability at distance 0 ), (2) the structural component, which describes spatially correlated variability, (3) sill, which is total variability, or sample variance, and (4) lag distance, which is the distance within which the variable is spatially dependent and beyond which is spatially 
independent. Randomness results when the nugget effect is high enough to closely approach the sill (i.e., ratio of nugget to sill is unity). Linearity occurs when there is spatial dependence at scales at least as great as the extent sampled.

Expected species-accumulation curves (samplebased rarefaction, sensu Gotelli and Colwell 2001) were created for each site using the EstimateS software (Colwell et al. 2004). Of particular interest was the calculation of $95 \%$ confidence intervals using formulas from Colwell et al. (2004) to estimate minimum plot number required to characterize representative species richness for each site. We defined minimum plot number as the number of plots yielding an upper $95 \%$ confidence interval that most closely approximated the total species richness of the site (Small and McCarthy 2002).

Our sampling represents a non-replicated study which employed a single intensively sampled area within each land-use site, an approach common in studies that focus on fine-scale spatial heterogeneity (e.g., Schlesinger et al. 1996); thus, interpretation of results should be made with that in mind.

\section{Results}

A total of 42 vascular plant species were encountered in all $501-\mathrm{m}^{2}$ plots from both pasture and old-field sites (Table 1). These sites differed significantly for most soil and plant variables. In particular, the old field had significantly higher net $\mathrm{N}$ mineralization/ nitrification, extractable $\mathrm{NO}_{3}, \mathrm{pH}, \mathrm{Ca}, \mathrm{Mg}, \mathrm{Al}$, plant cover, and species diversity, richness, and evenness (Table 2). Note that cover for pasture and old field was greater than $100 \%$. This is the result of overlapping foliar biomass and indicates that leaf area index was greater than 1 for both sites. There were also sharp contrasts between sites for correlations among most soil variables (Table 3 ).

Multiple regression using backwards stepwise analysis revealed that plant cover and all variables associated with plant biodiversity (species diversity, richness, and evenness) were significantly related to varying combinations of soil characteristics in the pasture, including available $\mathrm{N}$, organic matter, moisture, $\mathrm{pH}, \mathrm{Ca}$, and $\mathrm{Mg}$. By contrast, only cover was significantly related to soil characteristics (organic matter and moisture) in the old field (Table 4).

Pasture and old-field sites were dominated by contrasting plant species. Poa spp. dominated the old field, representing just over $25 \%$ of the total cover of the site; the top three species (Poa spp., Ambrosia artemisiifolia, and Verbesina alternifolia) combined to represent slightly less than $50 \%$ of total old-field cover (Table 5). The pasture was dominated by Festuca elatior, which was just under $40 \%$ of total cover, with the top two species (Festuca elatior and Aster pilosus) combining for nearly $70 \%$ total cover for the pasture (Table 6).

Geostatistics showed that pasture and old-field sites contrasted with respect to spatial pattern of soils and plant cover. The old field exhibited significant spatial dependence for all soil variables except $\mathrm{Mg}$
Table 2 Soil and vegetation variables (mean \pm 1 standard error of mean) in $1-\mathrm{m}^{2}$ plots $(n=25)$ within pasture and old-field sites

Significant differences between means determined by $t$-tests (Zar 2009). Significant differences between sites at $P<0.05$, $P<0.01$, and $P<0.001$ indicated by $*, * *$, and ***, respectively. Note that cover exceeds $100 \%$, indicating leaf area index $>1$

\begin{tabular}{|c|c|c|c|}
\hline Variable & Pasture & Old field & $t$ \\
\hline Net $\mathrm{N}$ mineralization rate $(\mu \mathrm{g} \mathrm{N} / \mathrm{g}$ soil/day) & $0.5 \pm 0.2$ & $1.4 \pm 0.2$ & $3.1 * *$ \\
\hline Net nitrification ( $\mu \mathrm{g} \mathrm{NO}_{3}-\mathrm{N} / \mathrm{g}$ soil/day) & $0.7 \pm 0.2$ & $1.6 \pm 0.2$ & $3.1 * *$ \\
\hline $\mathrm{NH}_{4}$ pool $\left(\mu \mathrm{g} \mathrm{NH}_{4}-\mathrm{N} / \mathrm{g}\right.$ soil $)$ & $5.7 \pm 1.3$ & $8.5 \pm 0.9$ & 1.8 \\
\hline $\mathrm{NO}_{3}$ pool $\left(\mu \mathrm{g} \mathrm{NO}_{3}-\mathrm{N} / \mathrm{g}\right.$ soil $)$ & $9.8 \pm 0.7$ & $6.6 \pm 0.5$ & $3.8^{* * * *}$ \\
\hline Organic matter $(\%)$ & $8.3 \pm 0.1$ & $8.1 \pm 0.2$ & 0.8 \\
\hline $\mathrm{pH}$ & $4.43 \pm 0.05$ & $4.56 \pm 0.03$ & $2.4^{*}$ \\
\hline $\mathrm{Ca}(\mu \mathrm{g} / \mathrm{g}$ soil $)$ & $769 \pm 129$ & $1036 \pm 43$ & 2.0 \\
\hline $\mathrm{Mg}(\mu \mathrm{g} / \mathrm{g}$ soil $)$ & $122 \pm 24$ & $335 \pm 11$ & $8.0 * * *$ \\
\hline Al $(\mu \mathrm{g} / \mathrm{g}$ soil $)$ & $0.5 \pm 0.3$ & $4.8 \pm 1.6$ & $2.7^{*}$ \\
\hline Species diversity $\left(H^{\prime}\right)$ & $1.38 \pm 0.03$ & $2.21 \pm 0.05$ & $13.6 * * *$ \\
\hline Species evenness $(J)$ & $0.78 \pm 0.01$ & $0.86 \pm 0.01$ & $4.3 * * *$ \\
\hline Species richness $\left(S-\right.$ species $\left./ \mathrm{m}^{2}\right)$ & $5.9 \pm 0.2$ & $13.4 \pm 0.5$ & $13.5^{* * *}$ \\
\hline Cover $(\%)$ & $180 \pm 6$ & $256 \pm 12$ & $5.6^{* * *}$ \\
\hline
\end{tabular}


Table 3 Correlation matrix for aluminum (Al), magnesium $\left(\mathrm{Mg}\right.$ ), calcium (Ca), soil moisture (Moist), $\mathrm{NH}_{4}$ and $\mathrm{NO}_{3}$ pools, net nitrification and $\mathrm{N}$-mineralization rates (Nit and $\mathrm{N}$-min, respectively), organic matter $(\mathrm{OM})$, and $\mathrm{pH}$ at old field and pasture sites of Mill Creek study area Wayne County, West Virginia

\begin{tabular}{|c|c|c|c|c|c|c|c|c|c|}
\hline & $\mathrm{Al}$ & $\mathrm{Ca}$ & $\mathrm{Mg}$ & Moist & $\mathrm{NH}_{4}$ & Nit & N-min & $\mathrm{NO}_{3}$ & $\mathrm{OM}$ \\
\hline \multicolumn{10}{|l|}{ Old field } \\
\hline $\mathrm{Ca}$ & -0.54 & & & & & & & & \\
\hline $\mathrm{Mg}$ & - & - & & & & & & & \\
\hline Moist & - & - & $0.51^{*}$ & & & & & & \\
\hline $\mathrm{NH}_{4}$ & - & - & - & - & & & & & \\
\hline Nit & - & - & - & - & - & & & & \\
\hline $\mathrm{N}-\min$ & - & - & - & - & - & $0.99^{\ddagger}$ & & & \\
\hline $\mathrm{NO}_{3}$ & - & - & - & - & - & - & - & & \\
\hline $\mathrm{OM}$ & - & - & $0.58^{\star}$ & $0.84^{\star}$ & - & - & - & - & \\
\hline $\mathrm{pH}$ & - & $0.62^{\ddagger}$ & - & $0.63^{*}$ & - & - & - & - & 0.64 \\
\hline \multicolumn{10}{|l|}{ Pasture } \\
\hline $\mathrm{Ca}$ & - & & & & & & & & \\
\hline $\mathrm{Mg}$ & $0.41^{\dagger}$ & $0.95^{\star}$ & & & & & & & \\
\hline Moist & - & - & - & & & & & & \\
\hline $\mathrm{NH}_{4}$ & - & - & - & - & & & & & \\
\hline Nit & - & - & - & - & $0.62^{\ddagger}$ & & & & \\
\hline $\mathrm{N}-\min$ & - & - & - & - & $0.43^{\dagger}$ & $0.97^{\star}$ & & & \\
\hline $\mathrm{NO}_{3}$ & - & - & - & - & $0.84^{\ddagger}$ & $0.64^{\ddagger}$ & $0.50^{\dagger}$ & & \\
\hline $\mathrm{OM}$ & - & - & - & $0.72^{\ddagger}$ & - & - & - & - & \\
\hline $\mathrm{pH}$ & - & - & $0.50^{\dagger}$ & - & - & - & - & - & - \\
\hline
\end{tabular}

Dashes (-) indicate no significant correlation. $N=25$ for both matrices

${ }^{\dagger} P<0.05,{ }^{*} P<0.01$

and $\mathrm{Al}$, whereas pasture soils lacked spatial dependence for net nitrification, $\mathrm{NH}_{4}$, organic matter, and $\mathrm{Al}$ (Table 7). The two sites were similar in exhibiting a high degree of spatial dependence for all plant variables, except that plant cover was not spatially dependent in the old field (Table 7).

Geostatistics further demonstrated variation among dominant species for each site with respect to patterns of spatial dependence. For the pasture, with Festuca elatior, Aster pilosus, and Poa sp. as the top three species based on cover, only A. pilosus exhibited spatial dependence. For the top three oldfield species, Poa sp. and Verbesina alternifolia were spatially dependent, whereas Ambrosia artemisiifolia was not (Table 8).

Canonical correspondence analysis revealed a wide scatter of sample plots for both sites, based on cover-weighted species composition, despite the contiguous nature of the sample design. For the oldfield site, extractable soil $\mathrm{Al}$ was the most important factor explaining similarities and differences in composition among plots (Fig. 2), whereas soil organic matter was the most important factor in the pasture (Fig. 3).

Expected species-accumulation curves showed that $95 \%$ confidence intervals most closely approximated total species richness at 14 and 15 plots for pasture and old-field sites, respectively. This close similarity in minimum plots number was in spite of sharp contrasts in species richness, with mean plot richness and total site richness for the old field being $13.2 \pm 3.7$ species/plot and 35 species, respectively, and $7.2 \pm 2.9$ species/plot and 18 species, respectively, for the pasture (Fig. 4).

\section{Discussion}

Not surprisingly, these two sites with contrasting land use differed greatly with respect to community 
Table 4 Multiple regression, using backward stepwise procedure, for vegetation variables at pasture and old-field sites

Species diversity

Old field

Not significant at $P<0.05$

Pasture

$$
H^{\prime}=2.46-0.25(\mathrm{pH}), r^{2}=0.16
$$

Species richness

Old field

Not significant at $P<0.05$

Pasture

$$
S=5.93+0.002(\mathrm{Ca})-0.02(\mathrm{Mg}), r^{2}=0.32
$$

Species evenness

Old field

Not significant at $P<0.05$

Pasture

$$
\begin{aligned}
& J=1.06+0.10(\text { organic matter })-0.03 \text { (moisture) }, \\
& r^{2}=0.50
\end{aligned}
$$

Cover

Old field

$$
\text { Cover }=376+100(\text { organic matter })-36 \text { (moisture) }
$$$$
r^{2}=0.52
$$

Pasture

$$
\text { Cover }=536-5\left(\mathrm{NH}_{4}\right)+9\left(\mathrm{NO}_{3}\right)-12(\text { moisture }),
$$$$
r^{2}=0.52
$$

Variables significantly accounting for variability in the model at $\mathrm{P}<0.05$ are listed with their coefficients. See Methods for further details

Original models:

$H^{\prime}=\mathrm{Al}+\mathrm{Ca}+\mathrm{Mg}+\mathrm{NH}_{4}+\mathrm{NO}_{3}+\mathrm{N}$

mineralization + nitrification + organic

matter $+\mathrm{pH}+$ moisture

$\mathrm{S}=\mathrm{Al}+\mathrm{Ca}+\mathrm{Mg}+\mathrm{NH}_{4}+\mathrm{NO}_{3}+\mathrm{N}$

mineralization + nitrification + organic

matter $+\mathrm{pH}+$ moisture

$J=\mathrm{Al}+\mathrm{Ca}+\mathrm{Mg}+\mathrm{NH}_{4}+\mathrm{NO}_{3}+\mathrm{N}$

mineralization + nitrification + organic

matter $+\mathrm{pH}+$ moisture

Cover $=\mathrm{Al}+\mathrm{Ca}+\mathrm{Mg}+\mathrm{NH}_{4}+\mathrm{NO}_{3}+\mathrm{N}$

mineralization + nitrification + organic

matter $+\mathrm{pH}+$ moisture

structure and composition. The old field had $>40 \%$ more plant cover than did the pasture and twofold higher species richness, which, along with higher evenness, resulted in higher species diversity (Table 2). The pasture was overwhelmingly domi-

\begin{tabular}{|c|c|}
\hline Species & Mean cover $(\%)$ \\
\hline Poa sp. & 64.6 \\
\hline Ambrosia artemisiifolia & 29.4 \\
\hline Verbesina alternifolia & 24.0 \\
\hline Panicum anceps & 16.8 \\
\hline Setaria viridis & 12.4 \\
\hline Elephantopus carolinianus & 12.2 \\
\hline Lespedeza cuneata & 12.0 \\
\hline Glechoma hederacea & 10.0 \\
\hline Potentilla simplex & 8.8 \\
\hline Aster pilosus & 8.0 \\
\hline Panicum sp. & 7.8 \\
\hline Oxalis stricta & 7.4 \\
\hline Eupatorium coelestinum & 6.2 \\
\hline Ruellia caroliniensis & 6.0 \\
\hline Triodia flava & 4.8 \\
\hline Andropogon virginicus & 4.0 \\
\hline Festuca elatior & 3.4 \\
\hline Cirsium vulgare & 2.2 \\
\hline Paspalum leave & 2.2 \\
\hline Holcus lanatus & 1.8 \\
\hline Lespedeza sp. & 1.8 \\
\hline Eragrostis spectabilis & 1.6 \\
\hline Acalypha rhomboidea & 1.2 \\
\hline Panicum clandestinum & 1.2 \\
\hline Juncus tenuis & 1.0 \\
\hline Muhlenbergia sp. & 1.0 \\
\hline Erigeron canadensis & 0.8 \\
\hline Trifolium pratense & 0.8 \\
\hline Daucus carota & 0.6 \\
\hline Plantago sp. & 0.4 \\
\hline Taraxacum officinale & 0.4 \\
\hline Vernonia altissima & 0.4 \\
\hline Eupatorium serotinum & 0.2 \\
\hline Medicago sp. & 0.2 \\
\hline
\end{tabular}
nated by Festuca elatior (Table 5), one of the most commonly planted pasture species (Smith 1995). With a mean cover of $>70 \%, F$. elatior exhibited a
Table 5 Species encountered within a 5-m $\times 5-\mathrm{m}$ site located within an old field in Wayne County, WV

Order based on mean percent cover for $n=251-\mathrm{m}^{2}$ plots

degree of dominance in the pasture not seen in the old field. Its single-species relative cover of $>40 \%$ was similar to the sum of relative cover of the top three old-field taxa (Poa spp., Ambrosia artemisiifolia, and Verbesina alternifolia)_all of which are common constituents of fields following agricultural abandonment (Raynal and Bazzaz 1975; DeSteven 1991; USDA 2004) (Table 6). 
Table 6 Species encountered within a 5-m $\times 5$-m site located within an abandoned pasture in Wayne County, WV

\begin{tabular}{lc}
\hline Species & Mean cover (\%) \\
\hline Festuca elatior & 71.0 \\
Aster pilosus & 58.4 \\
Poa sp. & 23.0 \\
Solanum carolinense & 7.2 \\
Cinna arundinacea & 7.0 \\
Vernonia altissima & 5.8 \\
Setaria glauca & 3.2 \\
Digitaria sanguinalis & 2.8 \\
Arthraxon hispidus & 2.6 \\
Elephantopus carolinianus & 1.8 \\
Juncus effusus & 1.8 \\
Carex vulpinoidea & 1.2 \\
Juncus tenuis & 1.2 \\
Phaseolus polystachios & 1.2 \\
Glechoma hederacea & 0.6 \\
Oxalis stricta & 0.6 \\
Panicum anceps & 0.6 \\
Cyperus strigosus & 0.2 \\
Taraxacum officinale & 0.2 \\
\hline Order based mean & \\
\hline
\end{tabular}

Order based on mean percent cover for $n=251-\mathrm{m}^{2}$ plots
There were also sharp contrasts in soils between the two sites, despite being of the same (Kanawha) series comprising deep alluvial parent materials. More notable differences were in soil $\mathrm{N}$ (net $\mathrm{N}$ mineralization/nitrification rates of old-field soils being twice that of the pasture) and extractable $\mathrm{Mg}$ and $\mathrm{Al}$, both significantly higher in old-field soils (Table 2).

Studies such as ours recall the circulus vitiosus first described by Jenny et al. (1969) to characterize the dilemma in distinguishing effects of soil on plants versus effects of plants on soil. Our data suggest that the reciprocating nature of these effects may itself vary with land-use history. Not only did spatial correlations (patterns) of soil constituents vary between pasture and old-field sites (Table 3), but the degree to which soil factors explained plant variables (via backward stepwise regression) was far greater in the pasture than in the old field (Table 4).

Equally clear, however, is the potential for plants to exert direct influences on soil (van der Krift and Berendse 2001). Wedin and Tilman (1990) provided strong evidence for the direct effects plants can have on soil. Focusing on plant-mediated changes in net $\mathrm{N}$

Table 7 Summary of geostatistical analyses of soil and vegetation variables for pasture and old-field sites

\begin{tabular}{|c|c|c|c|c|c|c|c|c|c|c|c|c|}
\hline \multirow[t]{2}{*}{ Variable } & \multicolumn{6}{|l|}{ Pasture } & \multicolumn{6}{|l|}{ Old field } \\
\hline & Model & Nugget & $\mathrm{C} 1$ & Sill & $\mathrm{N}: \mathrm{S}$ & A1 & Model & Nugget & $\mathrm{C} 1$ & Sill & $\mathrm{N}: \mathrm{S}$ & $\mathrm{A} 1$ \\
\hline $\mathrm{N}$ mineralization & Spherical & 0.57 & 0.04 & 0.61 & 0.93 & 3.49 & Spherical & 0.73 & 6.07 & 6.81 & 0.11 & 1.41 \\
\hline Nitrification & Linear & & & & & & Spherical & 0.00 & 0.78 & 0.78 & 0.00 & 0.25 \\
\hline $\mathrm{NH}_{4}$ & Linear & & & & & & Spherical & 0.06 & 13.12 & 13.18 & 0.00 & 0.13 \\
\hline $\mathrm{NO}_{3}$ & Spherical & 0.00 & 7.68 & 7.68 & 0.00 & 0.39 & Spherical & 0.00 & 6.80 & 6.80 & 0.00 & 0.37 \\
\hline Organic matter & Linear & & & & & & Spherical & 0.43 & 0.15 & 0.58 & 0.74 & 2.16 \\
\hline $\mathrm{pH}$ & Spherical & 0.03 & 0.05 & 0.08 & 0.34 & 4.45 & Spherical & 0.01 & 0.01 & 0.02 & 0.59 & 0.98 \\
\hline $\mathrm{Ca}$ & Random & & & & & & Spherical & 0.00 & 41757 & 41757 & 0.00 & 1.43 \\
\hline $\mathrm{Mg}$ & Spherical & 0.00 & 18147 & 18147 & 0.00 & 3.69 & Random & & & & & \\
\hline $\mathrm{Al}$ & Linear & & & & & & Linear & & & & & \\
\hline Cover & Spherical & 120.00 & 580.20 & 700.20 & 0.17 & 1.41 & Linear & & & & & \\
\hline Species richness & Spherical & 0.18 & 0.97 & 1.15 & 0.16 & 2.31 & Spherical & 0.56 & 0.41 & 0.97 & 0.58 & 4.14 \\
\hline Species evenness & Spherical & 0.002 & 0.001 & 0.003 & 0.62 & 1.23 & Spherical & 0.0003 & 0.004 & 0.004 & 0.09 & 2.75 \\
\hline Species diversity $\left(H^{\prime}\right)$ & Spherical & 0.01 & 0.01 & 0.02 & 0.32 & 1.31 & Spherical & 0.01 & 0.01 & 0.01 & 0.42 & 0.86 \\
\hline
\end{tabular}

"Sill" is calculated as the sum of "nugget" variance and structural variance ("C1"). "N:S" is the ratio of nugget to sill values. "A1" denotes the lag distance (in $\mathrm{m}$ ) within which a given variable is spatially dependent and beyond which is spatially independent. These statistics are not shown for variables for which the relationship between semi-variance and lag distance was either random or linear 
mineralization and nitrification, they grew monocultures of five perennial grass species in identical soil for 3 year and found up to 10-fold differences in rates of $\mathrm{N}$ dynamics. They also concluded that strong vegetation/soil feedbacks can exist in herb-dominated communities, such as those in our study, which can mediate processes that control species composition (Wedin and Tilman 1990).

Other studies have shown feedbacks involving plants and soil microbial communities (Bever 1994; Eskelinen et al. 2009). Although we did not characterize microbial communities directly in this study, we did assess microbially mediated processes-net $\mathrm{N}$ mineralization and nitrification-that varied substantially between site types (Table 2). It is possible that differences between sites in dominant grasses resulted in variation in soil microbes responsible for soil N dynamics. Bowman et al. (2006) demonstrated that Festuca species are capable of taking up essentially $100 \%$ of added $\mathrm{NH}_{4}$ in as short a period as $5 \mathrm{~h}$, precluding its availability to nitrifying bacteria and limiting net nitrification. This control on microbial processes can be maintained by efficient resorption of $\mathrm{N}$ by foliage (May et al. 2005), limiting $\mathrm{N}$ availability to $\mathrm{N}$-mineralizing microbes. By contrast, Paré et al. (2006) found that Poa species are relatively inefficient in taking up available $\mathrm{N}$, allowing more $\mathrm{NH}_{4}$ for nitrifier populations (increasing nitrification) and creating a positive feedback by resorbing less $\mathrm{N}$ and providing more organic $\mathrm{N}$ in foliage for $\mathrm{N}$ mineralizing microbes.

Evidence for these feedbacks can also be seen in results of geostatistical analyses. Because a nugget:sill ratio $(\mathrm{N}: \mathrm{S})$ of 1 indicates a random (rather than spatially dependent) pattern, the degree of spatial dependence is essentially inversely related to $\mathrm{N}: \mathrm{S}$. Thus, the $\mathrm{N}: \mathrm{S}$ for net $\mathrm{N}$ mineralization in the pasture of 0.93 (Table 7) suggests that $\mathrm{N}$ mineralization in the pasture approached randomness (i.e., was only slightly spatially dependent). That observation, combined with a lack of spatial dependence for net nitrification, is consistent with the lack of spatial dependence for $F$. elatior (Table 8), which was over $40 \%$ of total cover for the pasture.

By contrast, both net $\mathrm{N}$ mineralization and net nitrification were highly spatially dependent in the old field ( $\mathrm{N}: \mathrm{S}=0.11$ and 0.00 , respectively), as was Poa sp., which dominated the old field (N:S $=0.00)$. Furthermore, the lag distance $(1.41 \mathrm{~m})$ for net $\mathrm{N}$ mineralization was similar to that for Poa sp. (1.87 m) (Tables 7, 8).

It is further notable that study sites varied in species evenness, with the old field having significantly higher evenness than the pasture (Table 2). Often included primarily as one of a suite of indices to characterize community structure and plant biodiversity (e.g., SHE analysis, Small and McCarthy 2002), evenness has also been shown to have significance at the ecosystem level. Wilsey and Potvin (2000) provided evidence that species evenness can play a direct, mechanistic role in determining and maintaining structure and function of old fields. Experimentally manipulating evenness and identity of dominant species (including Fragaria virginiana, Poa pratensis, and Taraxacum officionale) in an old field of Quebec, they found that total plant biomass increased linearly with species evenness, independent of dominant species. Using cover as a surrogate for biomass

Table 8 Summary of geostatistical analyses for dominant (top three, based on cover) species from pasture and old-field sites

\begin{tabular}{|c|c|c|c|c|c|c|}
\hline Site/species & Model & Nugget & $\mathrm{C} 1$ & Sill & $\mathrm{N}: \mathrm{S}$ & A1 \\
\hline \multicolumn{7}{|l|}{ Pasture } \\
\hline Festuca elatior & Linear & & & & & \\
\hline Aster pilosus & Spherical & 59.90 & 663.90 & 723.80 & 0.08 & 2.86 \\
\hline Poa sp. & Linear & & & & & \\
\hline \multicolumn{7}{|l|}{ Old field } \\
\hline Poa sp. & Spherical & 0.00 & 493.10 & 493.10 & 0.00 & 1.87 \\
\hline Ambrosia artemisiifolia & Linear & & & & & \\
\hline Verbesina alternifolia & Spherical & 60.58 & 455.7 & 516.28 & 0.12 & 4.68 \\
\hline
\end{tabular}

"Sill" is calculated as the sum of "nugget" variance and structural variance ("C1"). "N:S" is the ratio of nugget to sill values. "A1" denotes the lag distance (in $\mathrm{m}$ ) within which a given variable is spatially dependent and beyond which is spatially independent. These statistics are not shown for variables for which the relationship between semi-variance and lag distance was either random or linear 
(Gilliam and Turrill 1993), our results are consistent with their findings, with the old field having $>40 \%$ higher cover than the pasture (Table 2).

Old field and pasture sites also differed in soil factors that most directly influence species composition. Although canonical correspondence analysis identified plant cover as being of secondary importance at both sites, extractable aluminum (Al) and organic matter $(\mathrm{OM})$ were of primary importance at the old field and pasture, respectively (Figs. 2, 3). This contrast is particularly notable considering the abiotic versus biotic nature of these two soil variables. Soil $\mathrm{Al}$ is generally a product of weathering of parent material and, although not commonly analyzed in studies focusing on plant-soil interactions, has been shown to correlate well with plant species' distributions (Gilliam et al. 2005). Variation in $\mathrm{OM}$ is generally a function of above- and belowground inputs from vegetation, as well as rates of decomposition (Jackson and Caldwell 1993).

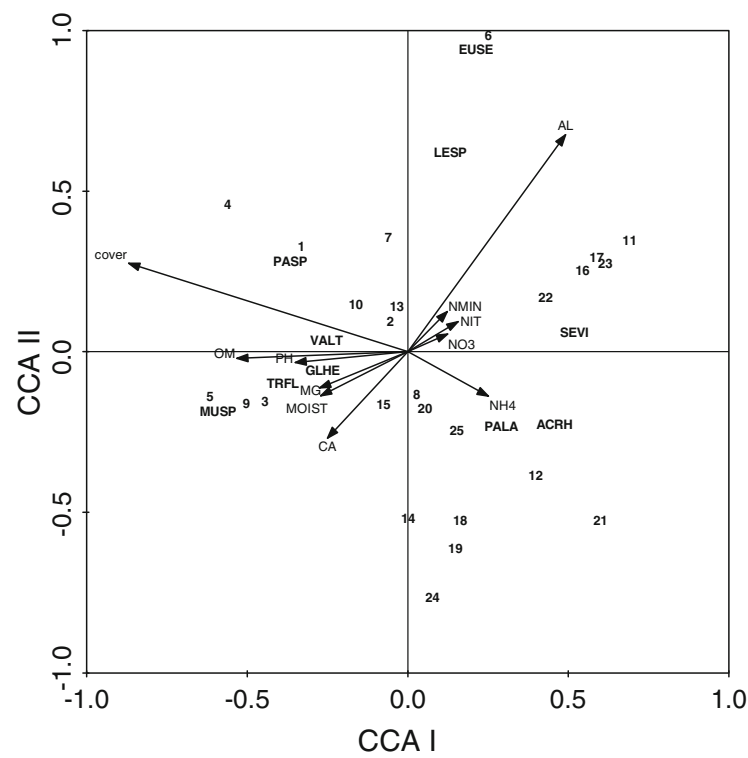

Fig. 2 Canonical correspondence analysis (CCA) ordination plot for the old-field site. Lines radiating from origin represent environmental gradients. Only the top 10 species (based on axis loading) are included: Eupatorium serotinum (EUSE), Lespedeza sp. (LESP), Panicum sp. (PASP), Vernonia altissima (VALT), Glechoma hederacea (GLHE), Setaria viridis (SEVI), Triodia flava (TRFL), Muhlenbergia sp. (MUSP), Paspalum laeve (PALA), Acalypha rhomboidea (ACRH). Numbers represent location of each of the 25 sample plots in ordination space (see Fig. 1). Eigenvalues: CCA I-0.222, CCA II-0.101; total inertia: 1.351; species-environment correlations: CCA I-0.94, CCA II -0.78

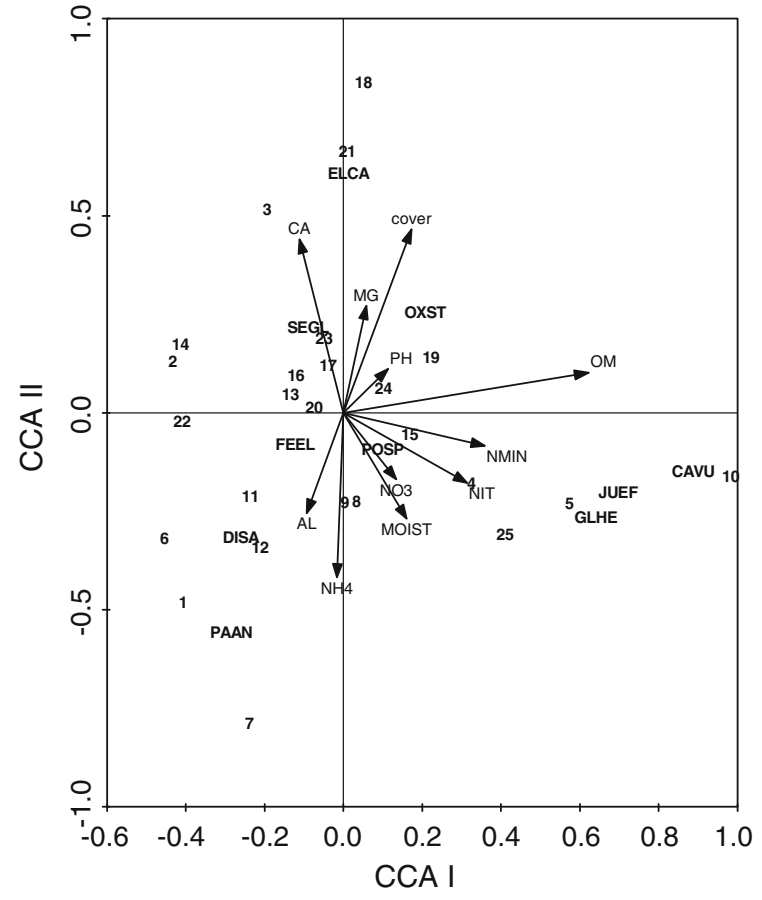

Fig. 3 Canonical correspondence analysis (CCA) ordination plot for the pasture site. Lines radiating from origin represent environmental gradients. Only the top 10 species (based on axis loading) are included: Elephantopus carolinianus (ELCA), Oxalis stricta (OXST), Digitaria sanguinalis (DISA), Festuca elatior (FEEL), Glechoma hederacea (GLHE), Setaria glauca (SEGL), Carex vulpinoidea (CAVU), Poa sp. (POSP), Panicum anceps (PAAN), Juncus effusus (JUEF). Numbers represent location of each of the 25 sample plots in ordination space (see Fig. 1). Eigenvalues: CCA I-0.125, CCA II-0.074; total inertia: 0.702; species-environment correlations: CCA I-0.89, CCA II- 0.90

Despite the $>2$-fold higher species richness of the old field versus the pasture (13 and 6 species $/ \mathrm{m}^{2}$, respectively), the minimum number of plots required to adequately characterize community composition was quite similar between the two sites (Fig. 4). Using an approach similar to that of Small and McCarthy (2002), we first created expected speciesaccumulation curves (which have also been called species-area curves and sample-based rarefactionGotelli and Colwell 2001) and then calculated minimum plot number as number of plots resulting in upper $95 \%$ confidence intervals closest to total species richness (35 vs. 18 species for old field and pasture, respectively). This method yielded minimum plot numbers of 15 and 14, respectively.

In conclusion, it is clear that two herbaceousdominated communities of contrasting land-use 


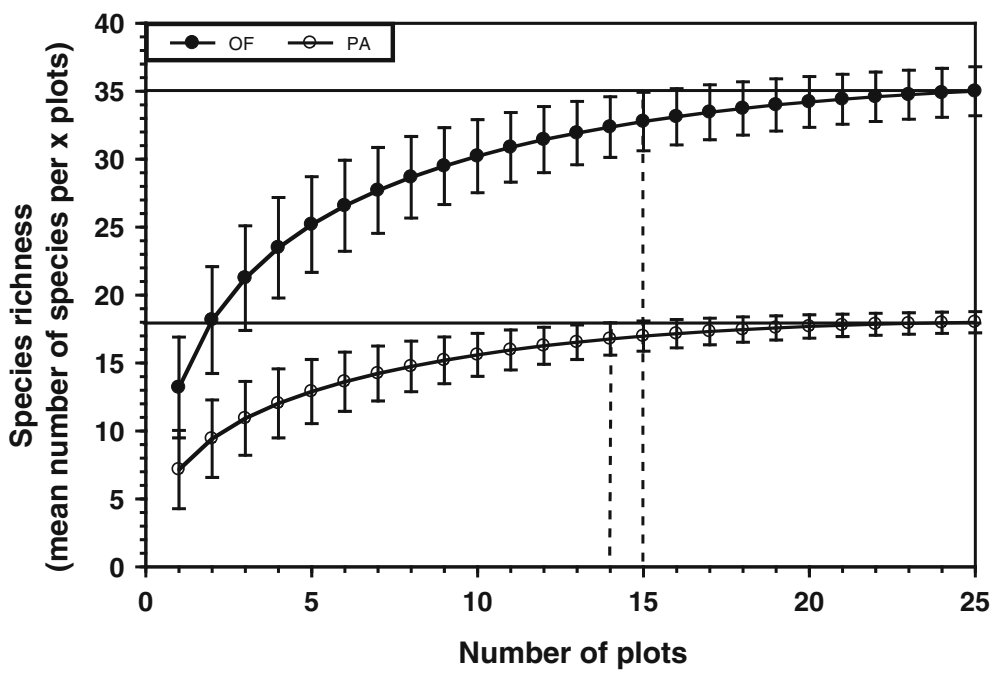

Fig. 4 Expected species-accumulation curves for old field (closed symbols) and pasture (open symbols) sites. Points shown are mean number of species for a given number of $1-\mathrm{m}^{2}$ sample plots; error bars are $\pm 95 \%$ confidence interval. Lines parallel to the $x$-axis that intersect the $y$-axis are total richness

history are profoundly different in several ways. Not only did they differ with respect to community composition (with Poa sp. and Festuca elatior clearly dominating old field and pasture sites, respectively) and structure (with the old field having $>40 \%$ greater plant cover), but they also varied with respect to soil chemistry and fertility. Furthermore, and more to the purpose of this study, these sites also varied in spatial pattern of vegetation, individual plant species, and soil. Fraterrigo and Rusak (2008) concluded that among the more profound influences of disturbance is a direct effect on spatial heterogeneity of ecological properties. Our results are consistent with this contention.

Acknowledgments This study was funded by Project ATI TRP 99-09 by the Nick J. Rahall II Appalachian Transportation Institute. We are grateful to Donnie Kinnan for his assistance in the field and laboratory. We are indebted to the plant taxonomic expertise of Dan Evans, Curator, Marshall University Herbarium (MUHW), for assistance in identifying plant specimens.

\section{References}

Analytical Software (2008) Statistix for windows, version 9.0 ed. Analytical Software, Tallahassee, FL for each site. The intersection of those lines with the respective upper 95\% confidence limit indicates minimum number of plots to characterize species richness representative of each site. The vertical dashed line represents minimum plot number

Barbour MG, Burk JH, Pitts WD, Gilliam FS, Schwartz MW (1999) Terrestrial plant ecology, 3rd edn. Benjamin/ Cummings, Menlo Park, CA

Beatty SW (2003) Habitat heterogeneity and maintenance of species in understory communities. In: Gilliam FS, Roberts MR (eds) The herbaceous layer in forests of eastern North America. Oxford University Press, New York, pp 177-197

Bever JD (1994) Feedback between plants and their soil communities in an old field community. Ecology 75: 1965-1977

Bowman DC, Cramer GR, Devitt DA (2006) Effect of salinity and nitrogen status on nitrogen uptake by tall fescue turf. J Plant Nutr 29:1481-1490

Colwell RK, Mao CX, Chang J (2004) Interpolating, extrapolating, and comparing incidence-based species accumulation curves. Ecology 85:2717-2727

DeSteven D (1991) Experiments on mechanisms of tree establishment in old-field succession: seedling survival and growth. Ecology 72:1076-1088

Dick DA, Gilliam FS (2007) Spatial heterogeneity and dependence of soils and herbaceous plant communities in adjacent seasonal wetland and pasture sites. Wetlands 27:951-963

Dufour A, Gadallah F, Wagner HH, Guisan A, Buttler A (2006) Plant species richness and environmental heterogeneity in a mountain landscape: effects of variability and spatial configuration. Ecography 29:573-584

Dutilleul P (1993) Spatial heterogeneity and the design of ecological field experiments. Ecology 74:1646-1658

Eskelinen A, Stark S, Männistö M (2009) Links between plant community composition, soil organic matter quality and 
microbial communities in contrasting tundra habitats. Oecologia 161:113-123

Evans DK, Weir Z, Carson C, Good C (2004) Vascular flora and plant communities-cover types at Mill Creek, Wayne County West Virginia. Report for West Virginia Department of Transportation, Charleston, West Virginia

Fraterrigo JM, Rusak JA (2008) Disturbance-driven changes in the variability of ecological patterns and processes. Ecol Lett 11:756-770

Gilliam FS (2006) Response of the herbaceous layer of forest ecosystems to excess nitrogen deposition. J Ecol 94: 1176-1191

Gilliam FS, Turrill NL (1993) Herbaceous layer cover and biomass in young versus mature stands of a Central Appalachian hardwood forest. Bull Torrey Bot Club 120:445-450

Gilliam FS, Lyttle NL, Thomas A, Adams MB (2005) Soil variability along a nitrogen mineralization/nitrification gradient in a nitrogen-saturated hardwood forest. Soil Sc Soc Am J 69:247-256

Gotelli N, Colwell RK (2001) Quantifying biodiversity: procedures and pitfalls in the measurement and comparison of species richness. Ecol Lett 4:379-391

Housman MJ, Yeager CM, Darby BJ, Sanford RL Jr, Kuske CR, Neher DA, Belnap J (2007) Heterogeneity of soil nutrients and subsurface biota in a dryland ecosystem. Soil Biol Biochem 39:2138-2149

Hutchings MJ, John E, Wijesinghe DK (2003) Toward understanding the consequences of soil heterogeneity for plant populations and communities. Ecology 84: 2322-2334

Iqbal J, Thomasson JA, Jenkins JN, Owens PR, Whisler FD (2005) Spatial variability analysis of soil physical properties of alluvial soils. Soil Sci Soc Am J 69:1338-1350

Jackson RB, Caldwell MM (1993) Geostatistical patterns of soil heterogeneity around individual perennial plants. J Ecol 81:683-692

Jenny H, Arkley RJ, Schultz AM (1969) The pygmy forestpodsol ecosystem and its dune associates of the Mendocino coast. Madroño 20:60-74

Kreft H, Jetz W (2007) Global patterns and determinants of vascular plant diversity. Proc Natl Acad Sci 104: 5925-5930

Lovett GM, Jones CG, Turner MG, Weathers KC (eds) (2005) Ecosystem function in heterogeneous landscapes. Springer, New York

Lundholm JT, Larson DW (2003) Relationships between spatial environmental heterogeneity and plant species diversity on a limestone pavement. Ecography 26:715-722

May JD, Burdette E, Gilliam FS, Adams MB (2005) Interspecific divergence in foliar nutrient dynamics and stem growth in a temperate forest in response to chronic nitrogen inputs. Can J For Res 35:1023-1030

McClain ME, Boyer EW, Dent CL, Gergel SE, Grimm NB, Groffman PM, Hart SC, Harvey JW, Johnston CA, Mayorga E, McDowell WH, Pinay G (2003) Biogeochemical hot spots and hot moments at the interface of terrestrial and aquatic ecosystems. Ecosystems 6:301-312
Minasny B, McBratney AB, Whelan BM (2005) VESPER version 1.62. Australian Centre for Precision Agriculture, McMillan Building A05, The University of Sydney, New South Wales 2006. http://www.usyd.edu.au/su/agric/acpa

Palmer MW (1990) Spatial scale and patterns of speciesenvironment relationships in hardwood forest of the North Carolina piedmont. Coenoses 5:79-87

Paré K, Chantigny MH, Carey K, Johnston WJ, Dionne J (2006) Nitrogen uptake and leaching under annual bluegrass ecotypes and bentgrass species: a lysimeter experiment. Crop Sci 46:847-853

Parkin TB (1993) Spatial variability of microbial processes in soil: a review. J Environ Qual 22:409-417

Raynal DJ, Bazzaz FA (1975) Interference of winter annuals with Ambrosia artemisiifolia in early successional fields. Ecology 56:35-49

Ricklefs RE (1977) Environmental heterogeneity and plant species diversity. Am Nat 111:376-381

Robertson GP (1987) Geostatistics in ecology: interpolating with known variance. Ecology 68:744-748

Robertson GP, Hutson MA, Evans FC, Tiedje JM (1988) Spatial variability in a successional plant community: patterns of nitrogen availability. Ecology 69:1517-1524

Schenk HJ, Jackson RB (2002) The global biogeography of roots. Ecol Monogr 72:311-328

Schlesinger WH, Raikes JA, Hartley AE, Cross AF (1996) On the spatial pattern of soil nutrients in desert ecosystems. Ecology 77:364-374

Slagle A, Skousen J, Bhumbla D, Sencindiver J, McDonald L (2004) Trace element concentrations of three soils in central Appalachia. Soil Surv Horiz 45:73-85

Small CJ, McCarthy BC (2002) Spatial and temporal variability of herbaceous vegetation in an eastern deciduous forest. Plant Ecol 164:37-48

Smith AE (ed) (1995) Handbook of weed management systems. Marcel Dekker, New York

Strasbaugh PD, Core EL (1977) Flora of West Virginia, 2nd edn. Seneca Books, Inc., Morgantown, WV

Thompson TL, Zaady E, Huancheng P, Wilson TB, Martens DA (2006) Soil C and N pools in patchy shrublands of the Negev and Chihuahuan Deserts. Soil Biol Biochem 38:1943-1955

USDA, NRCS (2004) The PLANTS database, version 3.5 (http://plants.usda.gov). National Plant Data Center, Baton Rouge, LA 70874-4490, USA

van der Krift TAJ, Berendse F (2001) The effect of plant species on soil nitrogen mineralization. J Ecol 89:555-561

Wedin D, Tilman D (1990) Species effects on nitrogen cycling: a test with perennial grasses. Oecologia 84:433-441

Wilsey BJ, Potvin C (2000) Biodiversity and ecosystem functioning: importance of species evenness in an old field. Ecology 81:887-892

Xi W, Peet RK, Urban DL (2008) Changes in forest structure, species diversity and spatial pattern following hurricane disturbance in a Piedmont North Carolina forest. USA J Plant Ecol 1:43-57

Zar JH (2009) Biostatistical analysis, 5th edn. Prentice Hall, Upper Saddle River, NJ 